\title{
ECSS \\ The Role of Oxygen Release from Li- and Mn-Rich Layered Oxides during the First Cycles Investigated by On-Line Electrochemical Mass Spectrometry
}

\author{
Benjamin Strehle, ${ }^{a, *, z}$ Karin Kleiner, ${ }^{\text {a,* }}$ Roland Jung, ${ }^{\text {a,* }}$ Frederick Chesneau, ${ }^{\text {b }}$ \\ Manuel Mendez, ${ }^{\mathrm{b}}$ Hubert A. Gasteiger, ${ }^{\mathrm{a}, * *}$ and Michele Piana ${ }^{\mathrm{a}, * * *}$ \\ ${ }^{a}$ Chair of Technical Electrochemistry, Department of Chemistry and Catalysis Research Center, \\ Technische Universität München, D-85748 Garching, Germany \\ ${ }^{b}$ BASF SE, GCN/EE - M311, D-67056 Ludwigshafen, Germany
}

\begin{abstract}
In the present work, the extent and the role of oxygen release during the first charge of lithium- and manganese-rich $\mathrm{Li}_{1.17}\left[\mathrm{Ni}_{0.22} \mathrm{Co}_{0.12} \mathrm{Mn}_{0.66}\right]_{0.83} \mathrm{O}_{2}$ (also referred to as $\mathrm{HE}-\mathrm{NCM}$ ) was investigated with on-line electrochemical mass spectrometry (OEMS). HE-NCM shows a unique voltage plateau at around $4.5 \mathrm{~V}$ in the first charge, which is often attributed to a decomposition reaction of the Li-rich component $\mathrm{Li}_{2} \mathrm{MnO}_{3}$. For this so-called "activation", it has been hypothesized that the electrochemically inactive $\mathrm{Li}_{2} \mathrm{MnO}_{3}$ would convert into $\mathrm{MnO}_{2}$ while lattice oxide ions are oxidized and released as $\mathrm{O}_{2}$ (or even $\mathrm{CO}_{2}$ ) from the host structure. However, qualitative and quantitative examination of the $\mathrm{O}_{2}$ and $\mathrm{CO}_{2}$ evolution during the first charge shows that the onset of both reactions is above the $4.5 \mathrm{~V}$ voltage plateau and that the amount of released oxygen is an order of magnitude too low to be consistent with the commonly assumed $\mathrm{Li}_{2} \mathrm{MnO}_{3}$ activation. Instead, the amount of released oxygen can be correlated to a structural rearrangement of the active material which occurs at the end of the first charge. In this process, oxygen depletion from the HE-NCM host structure leads to the formation of a spinel-like phase. This phase transformation is restricted to the near-surface region of the HE-NCM particles due to the poor mobility of oxide ions within the bulk. From the evolved amount of $\mathrm{O}_{2}$ and $\mathrm{CO}_{2}$, the thickness of the spinel-like surface layer was estimated to be on the order of $\approx 2-3 \mathrm{~nm}$, in excellent agreement with previously reported (S)TEM data.

(C) The Author(s) 2017. Published by ECS. This is an open access article distributed under the terms of the Creative Commons Attribution Non-Commercial No Derivatives 4.0 License (CC BY-NC-ND, http://creativecommons.org/licenses/by-nc-nd/4.0/), which permits non-commercial reuse, distribution, and reproduction in any medium, provided the original work is not changed in any way and is properly cited. For permission for commercial reuse, please email: oa@electrochem.org. [DOI: 10.1149/2.1001702jes] All rights reserved.

(cc) BY-NC-ND
\end{abstract}

Manuscript submitted September 8, 2016; revised manuscript received November 21, 2016. Published January 5, 2017.

Since the discovery of the positive electrode material $\mathrm{LiCoO}_{2}$ and its commercialization in the Li-ion technology by Sony in $1991,{ }^{1}$ analogous layered oxides $\left(\mathrm{LiMeO}_{2}, \mathrm{Me}=\mathrm{Ni}, \mathrm{Co}, \mathrm{Mn}, \mathrm{Al}\right.$, etc. $)$ were studied, aiming at higher intrinsic specific capacity, energy, stability, and lower costs. ${ }^{2-7}$ Among others, $\mathrm{Li}\left[\mathrm{Ni}_{1 / 3} \mathrm{Co}_{1 / 3} \mathrm{Mn}_{1 / 3}\right] \mathrm{O}_{2}$ (NCM-111) showed very interesting performances in terms of specific capacity and stability. ${ }^{8,9}$ Recently, materials characterized by an increase of exploitable $\mathrm{Li}^{+}$charge drew a lot of attention. ${ }^{10,11}$ These so-called $\mathrm{Li}$ rich compounds result from the substitution of part of the transition metal ions by $\mathrm{Li}^{+}$, in a structural arrangement closely related to the layered structure. ${ }^{11-14}$

$\mathrm{Li}_{2} \mathrm{MnO}_{3}$ (or $\mathrm{Li}\left[\mathrm{Li}_{1 / 3} \mathrm{Mn}_{2 / 3}\right] \mathrm{O}_{2}$ ) is the simplest structure in this category and crystallizes in the monoclinic system (space group $C 2 / \mathrm{m}$ ), while the common $\mathrm{LiMeO}_{2}$-based layered structures crystallize in the hexagonal system (space group $R-3 m$ ). ${ }^{11,13,14}$ The two structures are very close to each other despite this difference in symmetry, related simply to the $\mathrm{Li}^{+}$ordering in the transition metal sites. This similarity is evident in the structure of the Li-rich $\mathrm{NCM} \mathrm{Li} \mathrm{Li}_{1+\mathrm{x}} \mathrm{Me}_{1-\mathrm{x}} \mathrm{O}_{2}(\mathrm{Me}=$ $\mathrm{Ni}, \mathrm{Co}, \mathrm{Mn}$ ), also referred to as high-energy NCM (HE-NCM), where the hexagonal symmetry of the layered structure is broken by the superstructure of $\mathrm{Li}^{+}$in the transition metal sites, shown by the superlattice reflections in the diffractograms. ${ }^{15,16}$ This similarity makes the $\mathrm{Li}_{2} \mathrm{MnO}_{3}$ crystalline domains difficult to detect, for which typically the notation $x \mathrm{Li}_{2} \mathrm{MnO}_{3} \bullet(1-x) \mathrm{LiMeO}_{2}$ has been used. ${ }^{14,17,18}$

The higher lithium content of the HE-NCM material results in an increase in specific capacity and energy. Peculiar to this material is that the amount of lithium ions that can be deintercalated is higher than the possible increase in the valence of the transition metals. This was initially rationalized by the formation of an oxygen-deficient layered oxide throughout the bulk of the material, formed by oxygen loss during the first activation cycle. ${ }^{19,20}$ Accordingly, subsequent on-line mass spectrometry studies demonstrated the evolution of $\mathrm{O}_{2}$ during the first

\footnotetext{
*Electrochemical Society Student Member.

**Electrochemical Society Fellow.

****Electrochemical Society Member

${ }^{\mathrm{z}}$ E-mail: benjamin.strehle@tum.de
}

charge. ${ }^{21-23}$ The observed oxygen release was commonly attributed to $\mathrm{Li}_{2} \mathrm{MnO}_{3}$ activation and assigned to a unique plateau in the first charge of HE-NCM. ${ }^{24,25}$ In the proposed process, lattice $\mathrm{O}^{2-}$ anions are oxidized to $\mathrm{O}_{2}$ and removed from the oxide bulk structure, while the initially inactive manganese becomes electrochemically active after the first activation charge. However, very recently, an alternative view has been proposed, namely the direct involvement of lattice oxide ions by oxygen redox in the reversible charge/discharge reaction. ${ }^{26,27}$

The present paper will critically discuss the extent and the role of oxygen release from the HE-NCM host structure during the first activation charge. By means of quantitative on-line electrochemical mass spectrometry (OEMS) analysis of the amount of evolved oxygen and the onset potential of oxygen evolution it can be clearly shown that the $\mathrm{O}_{2}$ release does not take place during the $4.5 \mathrm{~V}$ plateau in the first charge (the so-called "activation"). Instead, we provide evidence that the $\mathrm{O}_{2}$ release occurs due to a structural rearrangement, consistent with the formation of a spinel-like surface layer observed in several (S)TEM studies. ${ }^{28-30}$ This hypothesis is in good agreement with the amount of oxygen observed in our study, which in turn would be too low for the previously proposed $\mathrm{Li}_{2} \mathrm{MnO}_{3}$ activation. ${ }^{17,24}$

\section{Experimental}

All experiments were conducted with $\mathrm{Li}_{1.17}\left[\mathrm{Ni}_{0.22} \mathrm{Co}_{0.12}\right.$ $\left.\mathrm{Mn}_{0.66}\right]_{0.83} \mathrm{O}_{2}$ (further on referred to as HE-NCM; BET $>>1 \mathrm{~m}^{2} \mathrm{~g}^{-1}$, BASF SE, Germany), which can also be written as $0.42 \mathrm{Li}_{2} \mathrm{MnO}_{3} \bullet$ $0.58 \mathrm{Li}\left[\mathrm{Ni}_{0.38} \mathrm{Co}_{0.21} \mathrm{Mn}_{0.41}\right] \mathrm{O}_{2}$. HE-NCM inks were prepared by mixing $96 \mathrm{wt} \%$ of HE-NCM, 2 wt\% of Super C65 conductive carbon (Timcal, Switzerland), and $2 \mathrm{wt} \%$ of polyvinylidene fluoride binder (PVDF, Kynar HSV 900, Arkema, France) with $N$-methyl-2-pyrrolidone (NMP, anhydrous, 99.5\%, Sigma-Aldrich, Germany) in a planetary orbital mixer (Thinky, USA) in several steps. In the case of standard electrodes for tests in Swagelok T-cells, the ink was coated onto an aluminum foil using a doctor blade at a wet-film thickness of $50 \mu \mathrm{m}$. For the OEMS measurements conducted in a specially designed cell, ${ }^{31}$ the ink was coated on a steel mesh (SS316, aperture $26 \mu \mathrm{m}$, wire diameter $25 \mu \mathrm{m}$, The Mesh Company Ltd, UK) in order to allow access of the 

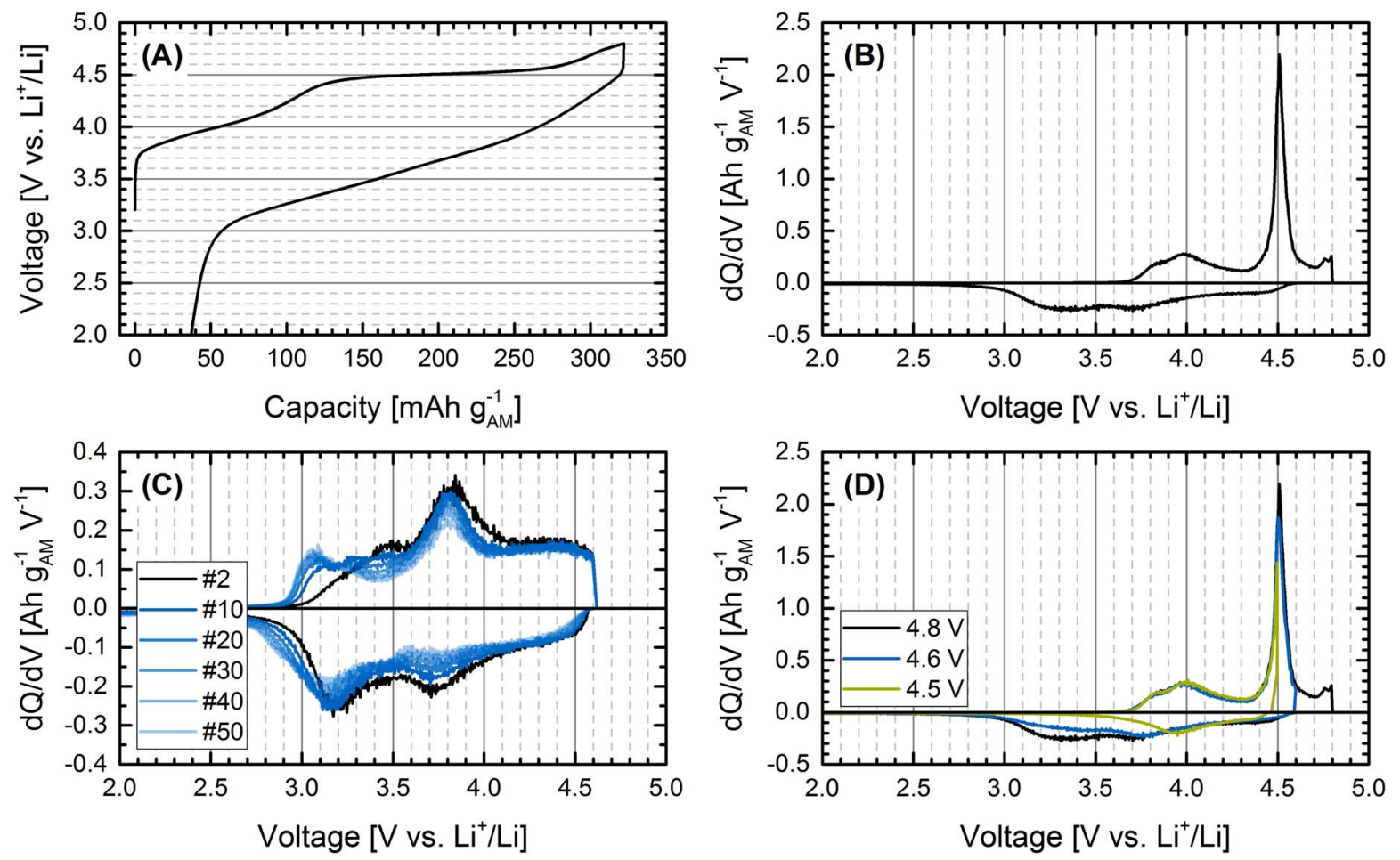

Figure 1. First cycle of HE-NCM (A) and the corresponding differential capacity (dQ/dV) plot (B). Panel C shows the differential capacity of the subsequent cycles. In panel $\mathrm{D}$, the $\mathrm{dQ} / \mathrm{dV}$ plot of the first cycle is shown for different upper voltage cutoffs, illustrating its influence on the discharge peaks. HE-NCM was cycled vs. metallic $\mathrm{Li}$ at a $\mathrm{C}$-rate of $\mathrm{C} / 10$ and $25^{\circ} \mathrm{C}$. In panel A-C, the first cycle was performed between $4.8 \mathrm{~V}$ and $2.0 \mathrm{~V}$, while the upper cutoff voltage was $4.6 \mathrm{~V}$ for the subsequent cycles.

evolved gases to the capillary leading to the mass spectrometer. ${ }^{32}$ The electrodes were punched out (loading/diameter: $\approx 4 \mathrm{mg}_{\mathrm{AM}} \mathrm{cm}^{-2}$ / $10 \mathrm{~mm}$ for T-cells and $\approx 10 \mathrm{mg}_{\mathrm{AM}} \mathrm{cm}^{-2} / 15 \mathrm{~mm}$ for OEMS cells), pressed for $20 \mathrm{~s}$ with 2.5 tons, and dried overnight at $120^{\circ} \mathrm{C}$ under dynamic vacuum. Swagelok T-cells were built using two glass fiber separators (glass microfiber filter, 691, VWR, Germany) and $120 \mu \mathrm{L}$ LP57 electrolyte (1 $\mathrm{M} \mathrm{LiPF}_{6}$ in EC:EMC $3: 7$ by weight, $<20 \mathrm{ppm} \mathrm{H}_{2} \mathrm{O}$, BASF SE). In contrast, OEMS cells were built using two porous polyolefin separators (H2013, Celgard, USA) and $100 \mu \mathrm{L}$ LP57. Metallic lithium foil (thickness $0.45 \mathrm{~mm}, 99.9 \%$, Rockwood Lithium, USA) was used as counter-electrode for all cells (diameter: $11 \mathrm{~mm}$ for Tcells and $17 \mathrm{~mm}$ for OEMS cells), except in one OEMS experiment, where a partially charged (delithiated) LFP counter-electrode with an areal capacity of $3.5 \mathrm{mAh} \mathrm{cm}^{-2}$ was used (from Custom Cells Itzehoe $\mathrm{GmbH}$, Germany), which was charged at $\mathrm{C} / 5$ by $3.0 \mathrm{mAh} \mathrm{cm}^{-2}$, corresponding to ca. $\mathrm{Li}_{0.14} \mathrm{FePO}_{4}$. Prior to cycling, the head space of the OEMS cells was purged for 2 min with argon to remove any gas traces from the glove box atmosphere. A $4 \mathrm{~h}$ OCV step was applied prior to starting the experiments. Conversion of the mass spectrometer currents to concentrations was done for $\mathrm{O}_{2}$ and $\mathrm{CO}_{2}$, using a calibration gas containing $2000 \mathrm{ppm}$ of each gas in $\mathrm{Ar}$ (Westfalen AG, Germany). C-rates are defined based on a specific capacity of $300 \mathrm{mAh} \mathrm{g}^{-1} \mathrm{AM}$ (AM $\equiv$ cathode active material, HE-NCM in our case).

\section{Results and Discussion}

Electrochemical characterization.-HE-NCM shows a unique activation cycle with a plateau around $4.5 \mathrm{~V}$ in the first charge to $4.8 \mathrm{~V}$ (Figure 1A), yielding an overall capacity of ca. $320 \mathrm{mAh}$ $\mathrm{g}^{-1} \mathrm{AM}$, which is close to the theoretical capacity of the material of ca. $360 \mathrm{mAh} \mathrm{g}^{-1} \mathrm{AM}$ (if one were to assume that all lithium could be extracted, based on $\mathrm{Li}_{1.17}\left[\mathrm{Ni}_{0.22} \mathrm{Co}_{0.12} \mathrm{Mn}_{0.66}\right]_{0.83} \mathrm{O}_{2}$ with a molar mass of $\left.86.8 \mathrm{~g} \mathrm{~mol}^{-1}\right)$. This can be seen more clearly in the differential capacity $(\mathrm{dQ} / \mathrm{dV})$ plot of the first charge/discharge cycle (Figure $1 \mathrm{~B})$, in which the activation plateau corresponds to a large peak at
4.5 $\mathrm{V}$ (HE-NCM vs. $\mathrm{Li}^{+} / \mathrm{Li}$ ). The presence of this peak is only observed in the first charge but not in the following cycles (Figure 1C). Depending on the voltage cutoff (before, on, or after the activation plateau), additional peaks appear at ca. $3.2 \mathrm{~V}$ and $3.7 \mathrm{~V}$ in the subsequent discharge cycles and at $3.0 \mathrm{~V}$ in the charge cycles (Figure 1C). The higher the end-of-charge voltage during the first activation cycle, the more pronounced are the additional peaks in the $\mathrm{dQ} / \mathrm{dV}$ plot (Figure 1D). Apart from the electrochemical characterization, XRD patterns of the pristine material and after the first cycle are shown in the Supporting Information. The weak reflections between 9 and $12^{\circ}$ are consistent with a two-phase rhombohedral-monoclinic system, ${ }^{33}$ which clearly assign the material to the class of $\mathrm{Li}$ - and $\mathrm{Mn}$-rich layered oxides (see Section 1 of the Supporting Information).

$\mathrm{Li}_{2} \mathrm{MnO}_{3}$ activation.-In the past, most authors have ascribed the origin of this so-called activation to the removal of oxygen from the bulk structure, leading to an oxygen-deficient bulk material. ${ }^{17,19-21,24,25,34}$ Some of them attributed the activation of HE$\mathrm{NCM}$ to the formation of delithiated $\mathrm{MnO}_{2}$ according to Eq. 1, 17,24 which can be reversibly lithiated in the following discharge:

$$
\mathrm{Li}_{2} \mathrm{MnO}_{3} \rightarrow 2 \mathrm{Li}^{+}+2 \mathrm{e}^{-}+\mathrm{MnO}_{2}+1 / 2 \mathrm{O}_{2} \uparrow
$$

If following Eq. 1, the quantitative activation of $\mathrm{Li}_{2} \mathrm{MnO}_{3}$ in our material with the composition $0.42 \mathrm{Li}_{2} \mathrm{MnO}_{3} \bullet 0.58$ $\mathrm{Li}\left[\mathrm{Ni}_{0.38} \mathrm{Co}_{0.21} \mathrm{Mn}_{0.41}\right] \mathrm{O}_{2}$ (molar mass $104.8 \mathrm{~g} \mathrm{~mol}^{-1}$ ) would lead to the release of ca. $2000 \mu \mathrm{mol}_{\mathrm{O}_{2}} \mathrm{~g}^{-1} \mathrm{AM}$, corresponding to ca. $17 \%$ of all oxygen atoms in HE-NCM (calculation given in Section 2 of the Supporting Information). This requires transport of oxygen anions from the bulk of the material to the surface during activation, from where it could be released as molecular oxygen.

Gas evolution during first charge.-Figure 2 shows OEMS data obtained while charging HE-NCM vs. metallic $\mathrm{Li}$ at $\mathrm{C} / 20$ up to $4.8 \mathrm{~V}$. Following the first constant current step (CC), one cell was held at open circuit voltage (OCV, black curve in Figure $2 \mathrm{~A}$ ) for $10 \mathrm{~h}$, while 


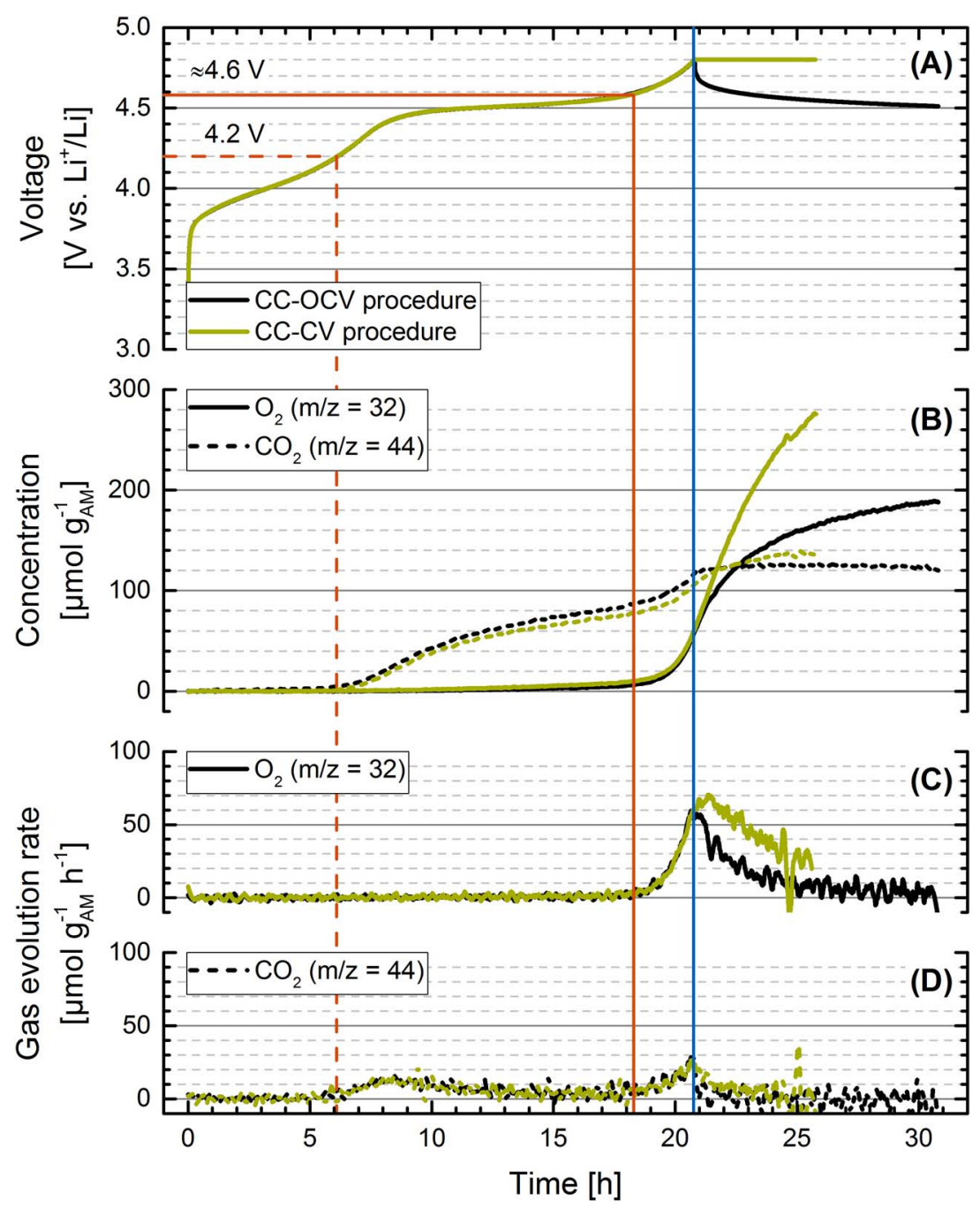

Figure 2. OEMS measurement of the first charge of HE$\mathrm{NCM}$ vs. metallic $\mathrm{Li}$ to $4.8 \mathrm{~V}$ at $\mathrm{C} / 20$ and $25^{\circ} \mathrm{C}$, followed by either an OCV step for $10 \mathrm{~h}$ (black curves) or a CV hold at $4.8 \mathrm{~V}$ for $5 \mathrm{~h}$ (green curves). Panel A shows the voltage curve vs. time (note that the curves are superimposed up to the upper cutoff voltage, i.e., up to ca. $21 \mathrm{~h}$ ). Panel B illustrates the evolved amount of $\mathrm{O}_{2}$ (solid curves) and $\mathrm{CO}_{2}$ (dashed curves) in units of $\mu \mathrm{mol} \mathrm{g}-1$ AM, whereas the $\mathrm{O}_{2}$ and $\mathrm{CO}_{2}$ evolution rates in units of $\mu \mathrm{mol} \mathrm{g}^{-1} \mathrm{AM} \mathrm{h}^{-1}$ are shown in the panels $\mathrm{C}$ and $\mathrm{D}$, respectively. The dashed red lines indicate the initial onset potential of $\mathrm{CO}_{2}$ evolution; the solid red lines indicate the onset potential of $\mathrm{O}_{2}$ evolution (as well as the second onset potential for $\mathrm{CO}_{2}$ evolution); the solid blue line marks the end of the $\mathrm{CC}$ charge at the cutoff voltage of $4.8 \mathrm{~V}$ another cell was held at $4.8 \mathrm{~V}$ in a constant voltage step $(\mathrm{CV}$, green curve in Figure 2A) for $5 \mathrm{~h}$, recording continuously the $\mathrm{O}_{2}$ and $\mathrm{CO}_{2}$ evolution in both cases (accumulated $\mathrm{O}_{2}$ and $\mathrm{CO}_{2}$ signals are shown in Figure $2 \mathrm{~B}$, while the evolution rates of $\mathrm{O}_{2}$ and $\mathrm{CO}_{2}$ are shown in Figure 2C and Figure 2D, respectively).

Starting with the CC-OCV experiment (black lines in Figure 2), the $\mathrm{CO}_{2}$ evolution begins at $4.2 \mathrm{~V}$ (before the plateau), followed by a second increase at $\approx 4.6 \mathrm{~V}$ (after the plateau), which coincides with the onset potential for $\mathrm{O}_{2}$ evolution. While the $\mathrm{CO}_{2}$ release stops at the beginning of the OCV step, interestingly, the $\mathrm{O}_{2}$ evolution goes on and does not complete within the measurement time. Let us first examine the evolution of $\mathrm{CO}_{2}$. In agreement with Metzger et al., ${ }^{35}$ we attribute the initial $\mathrm{CO}_{2}$ evolution starting at $4.2 \mathrm{~V}$ (marked by the dashed red lines in Figure 2) to the decomposition of carbonate impurities on the surface of the HE-NCM particles. The $4.2 \mathrm{~V}$ onset potential agrees with the $\mathrm{Li}_{2} \mathrm{CO}_{3}$ oxidation potential reported in the literature, ${ }^{25,36,37}$ whereby essentially one $\mathrm{CO}_{2}$ molecule per $\mathrm{Li}_{2} \mathrm{CO}_{3}$ is produced. ${ }^{37}$ This first $\mathrm{CO}_{2}$ evolution process continues up to a potential of $\approx 4.6 \mathrm{~V}$ (marked by the solid red lines in Figure 2), beyond which a second increase of the $\mathrm{CO}_{2}$ evolution is observed. Note that the first process gradually levels off during the plateau, consistent with the consumption of an impurity which is only present in limited quantities. Up to $\approx 4.6 \mathrm{~V}, \approx 80 \mu \mathrm{mol}_{\mathrm{CO}_{2}} \mathrm{~g}^{-1}$ AM are evolved (Figure 2B), which for a 1:1 stoichiometric ratio between oxidized $\mathrm{Li}_{2} \mathrm{CO}_{3}$ and evolved $\mathrm{CO}_{2}$ would correspond to $\mathrm{Li}_{2} \mathrm{CO}_{3}$ content of $\approx 0.6 \mathrm{wt} \%$ (from: $80 \mu \mathrm{mol}_{\mathrm{CO}_{2}} \mathrm{~g}^{-1} \mathrm{AM} \cdot 74 \mathrm{~g}_{\mathrm{Li}_{2} \mathrm{CO}_{3}} \mathrm{~mol}^{-1}{ }_{\mathrm{Li}_{2} \mathrm{CO}_{3}}$ ). The calculated amount of $\mathrm{Li}_{2} \mathrm{CO}_{3}$ is to be expected on the HE-NCM particles (particularly in view of its rather high BET surface area ${ }^{23}$ ). This interpretation of the $\mathrm{CO}_{2}$ signal is at variance with the mechanism proposed by Streich et al. ${ }^{23}$ and by Luo et al., ${ }^{27}$ who concluded that the entire amount of $\mathrm{CO}_{2}$ evolved during the initial charging of $\mathrm{HE}-\mathrm{NCM}$ materials (i.e., including the $\mathrm{CO}_{2}$ evolved between $\approx 4.2$ and $\approx 4.6 \mathrm{~V}$ in their experiments) would originate from the attack of reactive oxygen species (e.g., superoxide radicals) released from the HE-NCM lattice on the electrolyte solvents. As evidence, Luo et al. noted the detection of $\mathrm{C}^{16 / 18} \mathrm{O}_{2}$ from their partially ${ }^{18} \mathrm{O}$-labeled active material, but since their isotopic labeling process (heating the synthesized material in ${ }^{18} \mathrm{O}_{2}$-containing gas at $800^{\circ} \mathrm{C}$ ) would also lead to the labeling of carbonate species, the formation of $\mathrm{C}^{16 / 18} \mathrm{O}_{2}$ can equally well be explained by the electrooxidation of $\mathrm{Li}_{2} \mathrm{CO}_{3}$ surface impurities. The latter are typically present in layered oxide materials. ${ }^{38-40}$ However, the detection of $\mathrm{C}^{16 / 18} \mathrm{O}_{2}$ during the entire charging curve shows that the anodic oxidation of the electrolyte (without any involvement of the active material), which would release solely $\mathrm{C}^{16 / 16} \mathrm{O}_{2}$ in the experiment by Luo et al., is of minor importance for this class of materials. Thus, while we disagree with the interpretation by Streich et al. ${ }^{23}$ and by Luo et al. ${ }^{27}$ that the evolved $\mathrm{CO}_{2}$ below $\approx 4.6 \mathrm{~V}$ originates from the reaction of the electrolyte with released lattice oxygen, we do believe that the second increase of the $\mathrm{CO}_{2}$ evolution rate above $4.6 \mathrm{~V}$, which coincides with the onset of $\mathrm{O}_{2}$ evolution, is indeed caused by this reaction.

Next we will examine the $\mathrm{O}_{2}$ evolution during the CC-OCV procedure. During the initial sloping region and during the high voltage plateau, i.e., at potentials below $\approx 4.6 \mathrm{~V}$ and a charge capacity of $\approx 280 \mathrm{mAh} \mathrm{g}^{-1} \mathrm{AM}$, only minute amounts of $\mathrm{O}_{2}$ are observed (less than $\left.10 \mu \mathrm{mol}_{\mathrm{O}_{2}} \mathrm{~g}^{-1} \mathrm{AM}\right)$. This number could account for only 
$\approx 1 \mathrm{mAh} \mathrm{g}^{-1}$ AM (assuming 4 electrons $/ \mathrm{O}_{2}$ ) and would thus be negligible compared to the overall charge capacity of $\approx 280 \mathrm{mAh} \mathrm{g}^{-1} \mathrm{AM}$. Therefore, since the lattice oxygen evolution happens only after the plateau at $4.5 \mathrm{~V}$, it cannot be correlated to the $\mathrm{Li}_{2} \mathrm{MnO}_{3}$ activation according to Eq. 1, as was done in some of the literature. ${ }^{17,24}$ Only at potentials above $\approx 4.6 \mathrm{~V}$, substantial $\mathrm{O}_{2}$ evolution is observed, reaching a total amount of $\approx 60 \mu \mathrm{mol}_{\mathrm{O}_{2}} \mathrm{~g}^{-1}$ AM once the positive voltage cutoff of $4.8 \mathrm{~V}$ is reached (see solid blue line in Figure 2). At this point, the charge capacity amounts to $\approx 310 \mathrm{mAh} \mathrm{g}^{-1} \mathrm{AM}$, of which only $\approx 6.4 \mathrm{mAh} \mathrm{g}^{-1}$ AM can be ascribed to the detected amount of $\mathrm{O}_{2}$. The $\mathrm{O}_{2}$ data may be compared to the study by Streich et al., ${ }^{23}$ who obtained $29 \mu \mathrm{mol}_{\mathrm{O}_{2}} \mathrm{~g}^{-1} \mathrm{AM}$ at a cutoff potential of $4.7 \mathrm{~V}$, in excellent agreement with the $\approx 25 \mu$ mol $_{\mathrm{O}_{2}} \mathrm{~g}^{-1}$ AM which we recorded at $4.7 \mathrm{~V}$ (Figure 2B). While the $\mathrm{O}_{2}$ evolution rate (Figure $2 \mathrm{C}$ ) is at its maximum at the positive voltage cutoff of $4.8 \mathrm{~V}, \mathrm{O}_{2}$ evolution continues even during the subsequent $\mathrm{OCV}$ period at a rate which decreases with decreasing potential. After $10 \mathrm{~h}$ of OCV, the potential decays to $\approx 4.5 \mathrm{~V}$, at which point the total amount of $\mathrm{O}_{2}$ approaches a value of $\approx 200 \mu$ mol $_{\mathrm{O}_{2}} \mathrm{~g}^{-1} \mathrm{AM}$ and the $\mathrm{O}_{2}$ evolution gradually stops. Consequently, the total amount of evolved $\mathrm{O}_{2}$ during the $\mathrm{CC}-\mathrm{OCV}$ procedure amounts to only $10 \%$ of what would be predicted on the basis of Eq. 1 (i.e., of $2000 \mu \mathrm{mol}_{\mathrm{O}_{2}} \mathrm{~g}^{-1} \mathrm{AM}$; see Section 2 of the Supporting Information). Note that the amount of $\mathrm{O}_{2}$ dissolved in the electrolyte accounts to ca. $0.1 \%$ of the overall $\mathrm{O}_{2}$ and is thus negligible compared to the gas phase which is detected by OEMS (calculation given in Section 3 of the Supporting Information). Even if we were to assume that all of the evolved $\mathrm{CO}_{2}\left(\approx 120 \mu \mathrm{mol}_{\mathrm{CO}_{2}} \mathrm{~g}^{-1} \mathrm{AM}\right)$ would derive from the oxidation of the electrolyte by released lattice oxygen, as was suggested by Luo et al. (assuming the formation of $1 \mathrm{~mol}$ of $\mathrm{CO}_{2}$ from $1 \mathrm{~mol}$ of released $\left.\mathrm{O}_{2}\right),{ }^{27}$ only $\approx 16 \%$ of the evolved $\mathrm{O}_{2}$ predicted by Eq. 1 would be released during the CC-OCV procedure. More likely, however, only $\approx 40 \mu \mathrm{mol}_{\mathrm{CO}_{2}} \mathrm{~g}^{-1} \mathrm{AM}$ derive from electrolyte oxidation by lattice oxygen (based on the above argument that $\mathrm{CO}_{2}$ formed up to $4.6 \mathrm{~V}$ is due to $\mathrm{Li}_{2} \mathrm{CO}_{3}$ oxidation), so that the maximum amount of released oxygen $\left(\approx 240 \mu \mathrm{mol} \mathrm{g}{ }^{-1}\right.$ AM $)$ amounts to $\approx 12 \%$ of what would be predicted by Eq. 1 .

One remaining unresolved phenomenon in the CC-OCV data in Figure 2 is the fact that the $\mathrm{CO}_{2}$ evolution stops very shortly after entering the OCV step (best seen by the $\mathrm{CO}_{2}$ trace in Figure $2 \mathrm{~B}$ ), despite the fact that the amount of $\mathrm{O}_{2}$ still increases by a factor of $\approx 3$ (see $\mathrm{O}_{2}$ trace in Figure 2B). This is clearly inconsistent with the above assumption that released lattice oxygen attacks the electrolyte solvents leading to $\mathrm{CO}_{2}$ formation. As it seems to be required that charge passes the external circuit, one could hypothesize an (independent) oxidation step of the electrolyte which would be suppressed during OCV. Furthermore, as the released lattice oxygen species is not known, the absent $\mathrm{CO}_{2}$ evolution might be explained by assuming that the oxidation of the electrolyte is largely triggered by superoxide radicals $\left(\mathrm{O}_{2}{ }^{\bullet-}\right)$ rather than by molecular oxygen, which was proposed previously for alkyl carbonate-based electrolytes ${ }^{41,42}$ as well as for the photo-assisted oxidation of organic dyes in aerated solutions. ${ }^{43}$ At cathode potentials significantly above $3 \mathrm{~V}$, superoxide radicals could only be formed by $\mathrm{O}_{2}$ reduction at the lithium anode, where it might proceed as long as lithium is deposited (i.e., as long as a fresh lithium is being plated). Under this assumption, superoxide radicals to decompose the alkyl carbonates to $\mathrm{CO}_{2}$ would be present during the $\mathrm{CC}$ step, but could not be supplied anymore during the OCV period. This will be discussed further when examining the gas evolution during the CC-CV charge.

Layered-to-spinel transformation.-Let us now summarize our observations so far: (i) almost no $\mathrm{O}_{2}$ from the HE-NCM host structure is released during the activation plateau, (ii) the total amount of evolved gases is roughly one order of magnitude lower than what would be predicted based on Eq. 1, and (iii) the $\mathrm{O}_{2}$ evolution continues during OCV, i.e., when no charge is passed. This provides strong evidence that the evolved $\mathrm{O}_{2}$ is not related to the bulk oxidation of the $\mathrm{Li}_{2} \mathrm{MnO}_{3}$ phase according to Eq. 1. In contrast, the negligible amount of $\mathrm{O}_{2}$ and the probably largely $\mathrm{Li}_{2} \mathrm{CO}_{3}$-derived
$\mathrm{CO}_{2}$ accumulated by the end of the voltage plateau (i.e., just below $4.6 \mathrm{~V}$ ) suggests that the following oxygen release is associated with a structural rearrangement of the surface of the HE-NCM material, rather than being related to the electrochemically driven process described traditionally by Eq. 1 . Such reactions are well-known from structurally related layered oxides and describe the chemical decomposition of $\mathrm{Li}_{\mathrm{x}} \mathrm{MeO}_{2}$ into a spinel-like structure with the composition $\mathrm{M}^{\prime}{ }_{3} \mathrm{O}_{4}\left(\mathrm{M}^{\prime}=\mathrm{Me}+\mathrm{Li}\right)$, shown in Eq. $2{ }^{44-46}$ This phase transformation is consistent with the observed phase reported in several (S)TEM studies from $\mathrm{Li}$ - and $\mathrm{Mn}$-rich layered oxides (an overview is provided in Section 4 of the Supporting Information). ${ }^{28-30,47-50}$ As the transition metal content in Li-rich materials is smaller than that for common layered oxides, the reaction is given in the generalized form for $\mathrm{Li}_{\mathrm{x}} \mathrm{Me}_{\mathrm{y}} \mathrm{O}_{2}$. Especially in the case of Ni-rich materials, ${ }^{51-55}$ the oxygen depletion of the near-surface region is a continuously ongoing process during cycling and/or at elevated temperatures, leading via the spinel structure to a rock-salt structure with the composition $\mathrm{M}^{\prime} \mathrm{O}\left(\mathrm{M}^{\prime}=\mathrm{Me}+\mathrm{Li}\right)$, described in Eq. $3{ }^{44,45}$ The restriction of these reactions to the near-surface region can be rationalized by the low $\mathrm{O}^{2-}$ anion mobility within the bulk material at/near room temperature.

$$
\begin{aligned}
& \mathrm{Li}_{\mathrm{x}} \mathrm{Me}_{\mathrm{y}} \mathrm{O}_{2} \rightarrow \frac{\mathrm{x}+\mathrm{y}}{3} \mathrm{Li}_{3-\frac{3 y}{x+y}} \mathrm{Me}_{\frac{3 y}{x+y}} \mathrm{O}_{4}+\frac{3-2(\mathrm{x}+\mathrm{y})}{3} \mathrm{O}_{2} \uparrow, \\
& \text { where } \mathrm{x} \ll 1 \text { and } \mathrm{y} \leq 1 \\
& \mathrm{Li}_{\mathrm{x}} \mathrm{Me}_{\mathrm{y}} \mathrm{O}_{2} \rightarrow \frac{\mathrm{x}+\mathrm{y}}{3} \mathrm{Li}_{3-\frac{3 y}{x+y}} \mathrm{Me}_{\frac{3 y}{\mathrm{x}+\mathrm{y}}} \mathrm{O}_{4}+\frac{3-2(\mathrm{x}+\mathrm{y})}{3} \mathrm{O}_{2} \uparrow \\
& \rightarrow(\mathrm{x}+\mathrm{y}) \mathrm{Li}_{1-\frac{\mathrm{y}}{\mathrm{x}+\mathrm{y}}} \mathrm{Me}_{\frac{\mathrm{y}}{\mathrm{x}+\mathrm{y}}} \mathrm{O}+\frac{2-(\mathrm{x}+\mathrm{y})}{2} \mathrm{O}_{2} \uparrow
\end{aligned}
$$

In summary, Equations 2 and 3 present an alternative view to Eq. 1 of the oxygen evolution mechanism for HE-NCM materials during activation, assuming that oxygen is released by the conversion of a layered oxide into a spinel (or rock-salt) structure at high potentials. This picture would be by analogy with thermally induced phase transformations observed for charged layered oxide materials. ${ }^{44-46,53}$

In the second experiment shown in Figure 2, a C/20 activation charge to $4.8 \mathrm{~V}$ and then continued with a constant voltage step for $5 \mathrm{~h}$ was performed (see green curves). Up to the positive cutoff potential of $4.8 \mathrm{~V}$, the voltage and gas evolution responses are identical with the foregoing experiment (compare green vs. black curves). The $\mathrm{O}_{2}$ evolution rate during the $4.8 \mathrm{~V}$ hold period is substantially larger than during OCV (see black vs. green solid curves in Figure 2C), so that the total amount of evolved oxygen is larger at the end of the CV step $\left(\approx 280 \mu \mathrm{mol}_{\mathrm{O}_{2}} \mathrm{~g}^{-1}\right.$ AM after $5 \mathrm{~h} \mathrm{CV}$ compared to $\approx 200 \mu \mathrm{mol}_{\mathrm{O}_{2}}$ $\mathrm{g}^{-1}$ AM after $10 \mathrm{~h} \mathrm{OCV}$, see Figure $2 \mathrm{~B}$ ). This seems to be at variance with our above assumption that the diffusion of $\mathrm{O}^{2-}$ anions within the bulk structure would limit the growth of the oxygen-depleted surface layer, i.e., that it would restrict the release of molecular oxygen to the near-surface region. However, since lithium deintercalation continues during the CV step (amounting to $\approx 20 \mathrm{mAh} \mathrm{g}^{-1} \mathrm{AM}$ ), the oxide material becomes even more unstable, so that it is not unreasonable to assume that this would lead either to a slightly increased $\mathrm{O}^{2-}$ diffusion and/or a further conversion of the spinel layer to a rock-salt structure (Eq. 3). Both effects would be accompanied by further $\mathrm{O}_{2}$ release. As the $\mathrm{O}_{2}$ evolution rate during the $\mathrm{CV}$ step diminishes in a similar way than during $\mathrm{OCV}$, we think that the oxygen depletion is still limited to the external part of the particles and does not affect the core of the particles. Note that Equation 2 and 3 describe the formation of the spinel (metal/oxygen ratio 3:4) and rock-salt structure (metal/oxygen ratio 1:1) with an ideal stoichiometry. However, it is also possible to reach stoichiometries in between in which the metal to oxygen ratio differs from the ideal case. Contrary to the CC-OCV experiment, the $\mathrm{CO}_{2}$ evolution continues at low rate during most of the $\mathrm{CV}$ step, which would be consistent with an oxidation step of the alkyl carbonates or the continuous formation of superoxide radicals during lithium plating on the anode. 


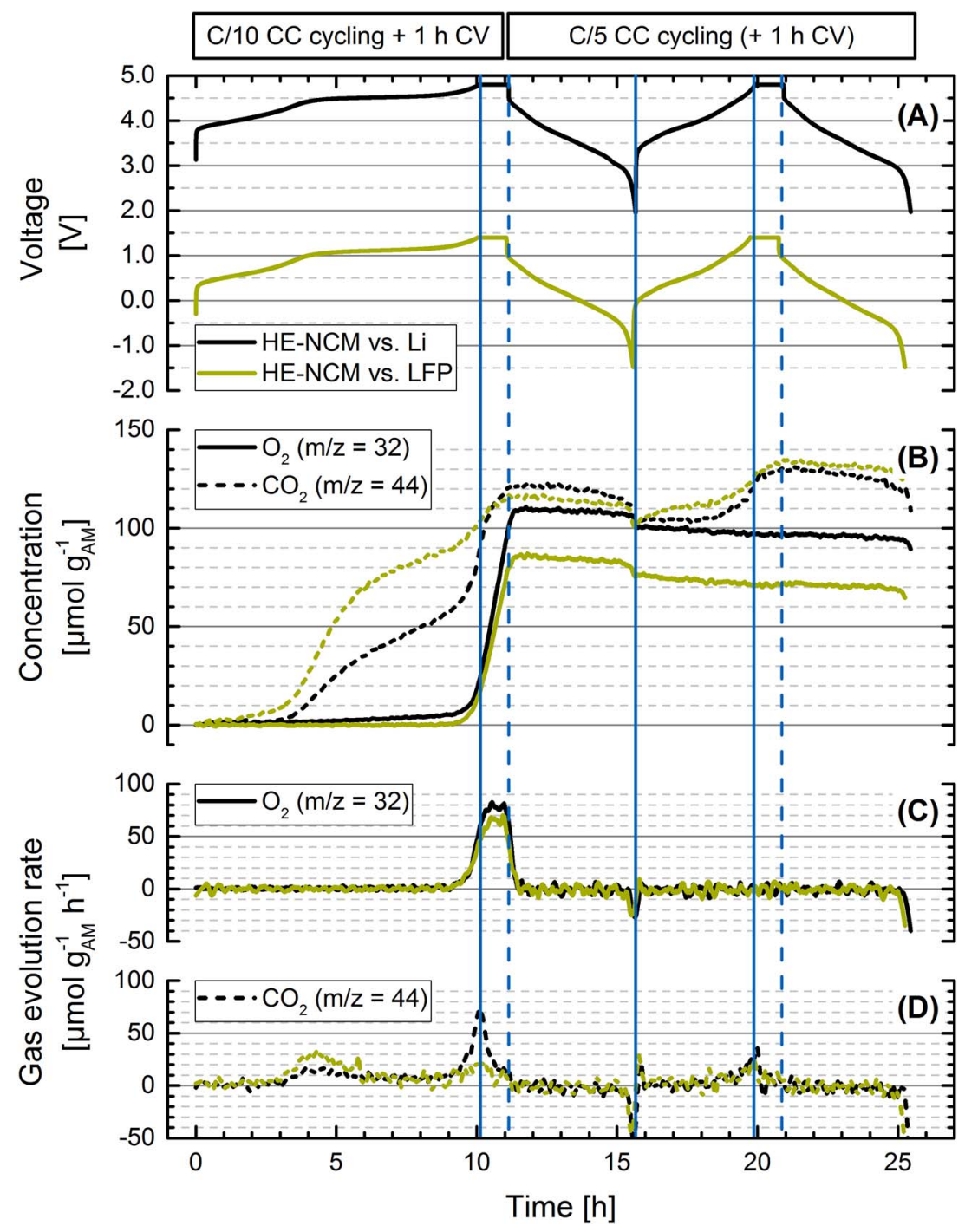

Figure 3. HE-NCM vs. Li (black curves) and HE-NCM vs. LFP (green curves), cycled at $\mathrm{C} / 10$ in the first charge and at $\mathrm{C} / 5$ in the subsequent discharge as well as the second cycle. Both measurements were performed at $25^{\circ} \mathrm{C}$ in the potential range of $2.0-4.8 \mathrm{~V}$ vs. $\mathrm{Li}^{+} / \mathrm{Li}$ for the HE-NMC workingelectrode, including a CV step of $1 \mathrm{~h}$ at the end of each CC charge. Panel A shows the voltage curves vs. time. Panel B illustrates the evolved amount of $\mathrm{O}_{2}$ (solid curves) and $\mathrm{CO}_{2}$ (dashed curves) in units of $\mu \mathrm{mol} \mathrm{g}{ }^{-1} \mathrm{AM}$, whereas the $\mathrm{O}_{2}$ and $\mathrm{CO}_{2}$ evolution rates in units of $\mu \mathrm{mol} \mathrm{g}^{-1} \mathrm{AM} \mathrm{h}^{-1}$ are shown in the panels $\mathrm{C}$ and $\mathrm{D}$, respectively. The blue solid lines indicate the end of the CC steps; the dotted blue lines show the end of the CV steps.

Gas evolution during the first two cycles.-After having examined the first activation charge, we now investigate whether $\mathrm{O}_{2}$ release from the HE-NCM host structure also occurs in the second cycle or not (Figure 3). Therefore, using first the same electrode configuration as was used in Figure 2 (viz., HE-NCM vs. Li), we performed a C/10 charge to $4.8 \mathrm{~V}$ completed with a CV step of $1 \mathrm{~h}$ and followed by a C/5 discharge to $2.0 \mathrm{~V}$, with a subsequent second cycle at C/5 (see black curves in Figure 3). Once the upper cutoff voltage is reached in this first charge at $\mathrm{C} / 10$, the amounts of evolved $\mathrm{O}_{2}$ and $\mathrm{CO}_{2}$ are lower than what we had observed at $\mathrm{C} / 20\left(\approx 25 \mu \mathrm{mol}_{\mathrm{O}_{2}} \mathrm{~g}^{-1}\right.$ AM and $\approx 90 \mu \mathrm{mol}_{\mathrm{CO}_{2}}$ $\mathrm{g}^{-1}{ }_{\mathrm{AM}}$ at $\mathrm{C} / 10$ vs. $\approx 60 \mu \mathrm{mol}_{\mathrm{O}_{2}} \mathrm{~g}^{-1}{ }_{\mathrm{AM}}$ and $\approx 105 \mu \mathrm{mol}_{\mathrm{CO}_{2}} \mathrm{~g}^{-1}{ }_{\mathrm{AM}}$ at $\mathrm{C} / 20$ ), which we ascribe to the slow kinetics of lattice oxygen release. However, at the end of the subsequent $1 \mathrm{~h}$ hold at $4.8 \mathrm{~V}$, the amounts of evolved $\mathrm{O}_{2}$ and $\mathrm{CO}_{2}$ are essentially identical for first cycle activation at either $\mathrm{C} / 10$ or $\mathrm{C} / 20\left(\approx 110 \mu \mathrm{mol}_{\mathrm{O}_{2}} \mathrm{~g}^{-1} \mathrm{AM}\right.$ and $\approx 120 \mu \mathrm{mol}_{\mathrm{CO}_{2}} \mathrm{~g}^{-1} \mathrm{AM}$ at $\mathrm{C} / 10+1 \mathrm{~h} \mathrm{CV}$ vs. $\approx 125 \mu \mathrm{mol}_{\mathrm{O}_{2}} \mathrm{~g}^{-1} \mathrm{AM}$ and $\approx 120 \mu \mathrm{mol}_{\mathrm{CO}_{2}} \mathrm{~g}^{-1} \mathrm{AM}$ at $\mathrm{C} / 20+1 \mathrm{~h} \mathrm{CV}$ ). It is noteworthy that the $\mathrm{O}_{2}$ evolution immediately stops upon switching from the CV step in the first cycle, during which $\mathrm{O}_{2}$ is still being evolved, to the first discharge step. The rapidly vanishing $\mathrm{O}_{2}$ evolution rate (Figure 3C) demonstrates that there is no delay between the $\mathrm{O}_{2}$ evolution from the HE-NCM material and its detection in the OEMS. As the near-surface region is lithiated and thus stabilized first during discharge, the abrupt end of the $\mathrm{O}_{2}$ evolution also shows that it must originate from the external part of the particles. Very surprising is the observation that there is no $\mathrm{O}_{2}$ evolution during the second charge, even though the overall amount of evolved $\mathrm{O}_{2}$ after the first charge at $\mathrm{C} / 10$ and $1 \mathrm{~h}$ hold at $4.8 \mathrm{~V}\left(\approx 110 \mu \mathrm{mol}_{\mathrm{O}_{2}} \mathrm{~g}^{-1} \mathrm{AM}\right)$ is less than what was measured in the previous experiments with a $\mathrm{C} / 20$ charge and $5 \mathrm{~h}$ hold at $4.8 \mathrm{~V}$ $\left(\approx 280 \mu \mathrm{mol}_{\mathrm{O}_{2}} \mathrm{~g}^{-1} \mathrm{AM}\right)$. Consequently, any formed spinel-like surface layer in the former case should be thinner and further $\mathrm{O}_{2}$ evolution in the second charge would be expected, contrary to what we and others ${ }^{23}$ have observed. In order to explain this discrepancy, we hypothesize that the initially formed surface layer is modified during the first discharge, thereby preventing further oxygen release in subsequent charges. In addition, the change in the HE-NCM bulk structure upon the initial release of almost all of its lithium ions during activation ( $320 \mathrm{mAh} \mathrm{g}^{-1} \mathrm{AM}$ in the first charge vs. a theoretical maximum of ca. $360 \mathrm{mAh} \mathrm{g}^{-1} \mathrm{AM}$ ) leads to different bulk thermodynamic properties, which might affect the oxygen release. Note that the overall capacity during the second charge decreases to ca. $275 \mathrm{mAh} \mathrm{g}^{-1}$ AM. The OEMS measurement shows also a slight decrease in the $\mathrm{O}_{2}$ and $\mathrm{CO}_{2}$ signals once the potential decreases below $3.0 \mathrm{~V}$ at the end of discharge, which can be attributed to the formation of $\mathrm{Li}_{2} \mathrm{O}_{2}$ and $\mathrm{Li}_{2} \mathrm{CO}_{3}$ on the HE-NCM surface. ${ }^{25,56}$ This newly formed $\mathrm{Li}_{2} \mathrm{CO}_{3}$ can then be oxidized in a subsequent charge, which we believe is the reason for the observed $\mathrm{CO}_{2}$ evolution in the second charge, starting again at $4.2 \mathrm{~V}$. This was already proposed previously. ${ }^{56}$

In order to ensure that no gaseous products are consumed on the Li counter-electrode, the same cycling procedure was applied to HE-NCM but using partially delithiated LFP as counter-electrode (green curves in Figure 3; see also in the experimental part). Neither $\mathrm{O}_{2}$ nor $\mathrm{CO}_{2}$ are expected to be reduced at the LFP potential. ${ }^{57}$ Its potential was monitored in a $\mathrm{T}$-cell with a $\mathrm{Li}$ reference-electrode to 
Table I. Estimation of the molar fraction and thickness of the spinel-like surface layer for $\mathrm{Model} \mathrm{A}$ (lattice oxygen-derived $\mathrm{CO}_{2}$ only above $\approx 4.6 \mathrm{~V})$ and $\mathrm{Model} B\left(\mathrm{CO}_{2}\right.$ evolved prior to $\mathrm{O}_{2}$ evolution at $\approx 4.6 \mathrm{~V}$ also due to the reaction with lattice oxygen), based on the gas evolution for the HE-NCM/Li cell data in Figure 3 (black lines). For $\mathrm{CO}_{2}$, we assume that both oxygen atoms come from the lattice $\mathrm{O}^{2-}$ anions, as suggested by Luo et al. ${ }^{27}$ The capacity is also derived from the gas evolution, assuming that four electrons are exchanged per gas molecule. For details see Section 5 and 6 of the Supporting Information.

\begin{tabular}{|c|c|c|c|c|c|}
\hline \multirow[b]{2}{*}{ Gas evolution } & \multirow[b]{2}{*}{$n\left[\mu \mathrm{mol} \mathrm{g}^{-1} \mathrm{AM}\right]$} & \multicolumn{2}{|c|}{ Model A $(\geq 4.6 \mathrm{~V})$} & \multicolumn{2}{|c|}{ Model $B(\geq 4.2 \mathrm{~V})$} \\
\hline & & $\begin{array}{l}\mathrm{O}_{2} \\
\mathrm{CO}_{2}\end{array}$ & $\begin{array}{l}110 \\
60\end{array}$ & $\begin{array}{l}\mathrm{O}_{2} \\
\mathrm{CO}_{2}\end{array}$ & $\begin{array}{l}110 \\
120\end{array}$ \\
\hline Capacity $\left(4 \mathrm{e}^{-} / \mathrm{O}_{2} \& \mathrm{CO}_{2}\right)$ & $C_{\text {spec }}\left[\mathrm{mAh} \mathrm{g}^{-1} \mathrm{AM}\right]$ & 18 & & 25 & \\
\hline Fraction of spinel phase & $x_{\text {spinel }}[\mathrm{mol} . \%]$ & 5.7 & & 7.7 & \\
\hline Spinel-like surface layer thickness & $t_{\text {spinel }}[\mathrm{nm}]$ & 2.1 & & 2.9 & \\
\hline
\end{tabular}

determine the voltage cutoffs in the HE-NCM/LFP full-cell for the OEMS measurement $(-1.45 \mathrm{~V}$ and $1.40 \mathrm{~V}$ selected as cell potential for the lower and upper voltage cutoffs). That the chosen cutoffs are reasonably comparable can be deduced from the close similarity of the charge/discharge curve features for the HE-NCM/Li and the HENCM/LFP cells (compare black and green curve in Figure 3A). The amount of evolved $\mathrm{O}_{2}$ after the first cycle is slightly lower for the HE-NCM/LFP cell compared to the HE-NCM/Li cell $\left(\approx 85 \mu \mathrm{mol}_{\mathrm{O}_{2}}\right.$ $\mathrm{g}^{-1}$ AM Vs. $\approx 110 \mu \mathrm{mol}_{\mathrm{O}_{2}} \mathrm{~g}^{-1} \mathrm{AM}$, respectively), but this might be due to small but finite differences in the upper voltage hold value. Regarding the $\mathrm{CO}_{2}$ evolution, there are clear differences prior to the onset of $\mathrm{O}_{2}$ evolution (reaching $\approx 90 \mu \mathrm{mol}_{\mathrm{CO}_{2}} \mathrm{~g}^{-1}$ AM for HE-NCM/LFP vs. $\approx 60 \mu \mathrm{mol}_{\mathrm{CO}_{2}} \mathrm{~g}^{-1} \mathrm{AM}$ for HE-NCM/Li), which might be due to an inhomogeneous distribution of carbonate impurities among different electrodes. Overall, however, the differences in total gas evolution are not very large, so that any possible "cross-talk" effects between anode and cathode are either negligible or very similar.

Thickness of the spinel-like surface layer-Assuming that the detected $\mathrm{O}_{2}$ as well as the associated $\mathrm{CO}_{2}$ obtained from Figure 3 derives from the formation of a near-surface spinel layer and not from the removal of oxygen from the bulk of the material, we will now estimate its thickness. The latter can be calculated by taking into account the amount of oxygen atoms which are released from the HENCM host structure according to Eq. 2. To perform this calculation, we will use two different models. Model A: We only consider the amount of gases evolved at a voltage higher than $4.6 \mathrm{~V}$, i.e., once the onset of $\mathrm{O}_{2}$ evolution is observed, which, without doubt, will derive from HE-NCM lattice oxygen. Model B: As some authors assume that the $\mathrm{CO}_{2}$ observed prior to $\mathrm{O}_{2}$ evolution (i.e., between $4.2 \mathrm{~V}$ and $4.6 \mathrm{~V}$ ) originates from electrolyte oxidation by reaction with released lattice oxygen, ${ }^{23,27}$ we will also provide an estimate for the near-surface layer thickness using the overall gas evolution (i.e., including the $\mathrm{CO}_{2}$ evolution starting at $4.2 \mathrm{~V}$ ), even though we believe that it is more likely due to the electrooxidation of $\mathrm{Li}_{2} \mathrm{CO}_{3}$ impurities. These two models will now be applied to the HE-NCM/Li cell data shown in Figure 3 (black lines). The formation of a spinel structure $\left(\mathrm{M}_{3}{ }_{3} \mathrm{O}_{4}, \mathrm{M}^{\prime}\right.$ $=\mathrm{Me}+\mathrm{Li}$ ) at $4.6 \mathrm{~V}$, corresponding to a charge capacity of $\approx 275 \mathrm{mAh}$ $\mathrm{g}^{-1} \mathrm{Am}$ at $\mathrm{C} / 10$, can be written as follows (see Supporting Information for more details):

$$
\mathrm{Li}_{0.28} \mathrm{Me}_{0.83} \mathrm{O}_{2} \rightarrow 0.37 \mathrm{Li}_{0.76} \mathrm{Me}_{2.24} \mathrm{O}_{4}+0.26 \mathrm{O}_{2} \uparrow
$$

Comparing the results in Table I, the difference between the two models is less than $1 \mathrm{~nm}$ which is reasonably small compared to the estimated average HE-NCM particle radius of $\approx 110 \mathrm{~nm}$ (see Section 6 of the Supporting Information) and based on the approximations used for this calculation. Nevertheless, the estimated thickness of $\approx 2-3 \mathrm{~nm}$ for the spinel-like phase is in excellent agreement with recent (S)TEM results, which propose also a 2-3 nm thick surface layer formed during the first cycle. ${ }^{28-30}$ As already mentioned in the discussion of Figure 2 , it is not possible to determine whether the transformation of the near-surface region stops at the spinel structure (as described in Eq. 2) and to what extent it may proceed all the way to the rock-salt structure (as described in Eq. 3). In the latter case, the estimated thickness of the near-surface layer would be smaller by a factor of ca. 2 . The overall maximum estimated capacity of $\approx 25 \mathrm{mAh} \mathrm{g}^{-1}$ AM is five times lower than the capacity provided by HE-NCM during the plateau. However, the gas evolution does not occur during the plateau but mostly after plateau at potentials of $4.6 \mathrm{~V}$ and above, proceeding even if HE-NCM is hold at open circuit potential after the first charge.

\section{Conclusions}

In the present work, we show the gas evolution of HE-NCM during the first two cycles using OEMS. The gas evolution can be divided into a $\mathrm{CO}_{2}$ evolution starting at $4.2 \mathrm{~V}$ and ending before $4.6 \mathrm{~V}$, followed by a second $\mathrm{CO}_{2}$ production starting at $4.6 \mathrm{~V}$ after the activation plateau and coinciding with the onset of the evolution of $\mathrm{O}_{2}$. In agreement with the literature $25,35,37,56$ and according to the use of a Li excess in HE-NCM synthesis, we attribute the $\mathrm{CO}_{2}$ evolution at low voltages mainly to the electrooxidation of $\mathrm{Li}_{2} \mathrm{CO}_{3}$ impurities, while the $\mathrm{O}_{2}$ and $\mathrm{CO}_{2}$ evolution at voltages higher than $4.6 \mathrm{~V}$ are both attributed to oxygen evolved from the HE-NCM lattice. We exclude any possible gas consumption on the $\mathrm{Li}$ counter-electrode by comparing the results obtained with LFP as counter-electrode. The maximum recorded gas evolution due to lattice oxygen upon extended potential hold at $4.8 \mathrm{~V}$ (see CC-CV experiment in Figure 2), $\approx 420 \mu \mathrm{mol} \mathrm{g}^{-1}$ AM (assuming that $\mathrm{CO}_{2}$ evolution at low potentials is due to electrolyte oxidation by released lattice oxygen) or $\approx 340 \mu \mathrm{mol} \mathrm{g}^{-1} \mathrm{AM}$ (assuming that $\mathrm{CO}_{2}$ evolution at low potentials is due to the oxidation of $\mathrm{Li}_{2} \mathrm{CO}_{3}$ impurities), is, in any case, at least 5-fold lower than what would be expected for the so-called $\mathrm{Li}_{2} \mathrm{MnO}_{3}$ activation $\left(2000 \mu \mathrm{mol} \mathrm{g}{ }^{-1} \mathrm{AM}\right)$ assumed in the literature. ${ }^{17,24}$ This led us to propose an alternative reaction to the $\mathrm{Li}_{2} \mathrm{MnO}_{3}$ activation, namely, the formation of a spinel-like nearsurface structure analogous to the known structural rearrangements in layered oxides. From the amount of evolved gases, we estimated the thickness of such a spinel-like surface layer on the HE-NCM particles to be on the order of $\approx 2-3 \mathrm{~nm}$, in excellent agreement with previously observed (S)TEM data. ${ }^{28-30}$

\section{Acknowledgments}

The authors gratefully acknowledge BASF SE for financial support of this research through the framework of its Scientific Network on Electrochemistry and Batteries. R.J. thanks BMW AG for funding.

\section{References}

1. K. Mizushima, P. C. Jones, P. J. Wiseman, and J. B. Goodenough, Mater. Res. Bull., 15, 783 (1980).

2. C. Delmas and I. Saadoune, Solid State Ionics, 53-56, 370 (1992).

3. T. Ohzuku, A. Ueda, and M. Kouguchi, J. Electrochem. Soc., 142, 4033 (1995).

4. T. Ohzuku and Y. Makimura, Chem. Lett., 30, 744 (2001).

5. J. S. Weaving, F. Coowar, D. A. Teagle, J. Cullen, V. Dass, P. Bindin, R. Green, and W. J. Macklin, J. Power Sources, 97-98, 733 (2001).

6. Z. Lu, D. D. MacNeil, and J. R. Dahn, Electrochem. Solid-State Lett., 4, A200 (2001).

7. F. Zhou, X. Zhao, and J. R. Dahn, J. Electrochem. Soc., 156, A343 (2009).

8. I. Belharouak, Y.-K. Sun, J. Liu, and K. Amine, J. Power Sources, 123, 247 (2003).

9. J. Choi and A. Manthiram, J. Electrochem. Soc., 152, A1714 (2005).

10. Z. Lu and J. R. Dahn, J. Electrochem. Soc., 149, A1454 (2002).

11. Z. Lu, L. Y. Beaulieu, R. A. Donaberger, C. L. Thomas, and J. R. Dahn, J. Electrochem. Soc., 149, A778 (2002). 
12. Y. S. Meng, G. Ceder, C. P. Grey, W. S. Yoon, M. Jiang, J. Bréger, and Y. Shao-Horn, Chem. Mater., 17, 2386 (2005).

13. N. Tran, L. Croguennec, C. Labrugère, C. Jordy, P. Biensan, and C. Delmas, J. Electrochem. Soc., 153, A261 (2006).

14. M. M. Thackeray, S.-H. Kang, C. S. Johnson, J. T. Vaughey, R. Benedek, and S. A. Hackney, J. Mater. Chem., 17, 3112 (2007).

15. J. Bréger, M. Jiang, N. Dupré, Y. S. Meng, Y. Shao-Horn, G. Ceder, and C. P. Grey, J. Solid State Chem., 178, 2575 (2005).

16. K. A. Jarvis, Z. Deng, L. F. Allard, A. Manthiram, and P. J. Ferreira, Chem. Mater. 23, 3614 (2011).

17. J.-S. Kim, C. S. Johnson, J. T. Vaughey, M. M. Thackeray, S. A. Hackney, W. Yoon, and C. P. Grey, Chem. Mater., 16, 1996 (2004).

18. M. M. Thackeray, C. S. Johnson, J. T. Vaughey, N. Li, and S. A. Hackney, J. Mater. Chem., 15, 2257 (2005).

19. Z. Lu and J. R. Dahn, J. Electrochem. Soc., 149, A815 (2002).

20. N. Tran, L. Croguennec, M. Ménétrier, F. Weill, P. Biensan, C. Jordy, and C. Delmas, Chem. Mater, 20, 4815 (2008).

21. A. R. Armstrong, M. Holzapfel, P. Novák, C. S. Johnson, S.-H. Kang, M. M. Thackeray, and P. G. Bruce, J. Am. Chem. Soc., 128, 8694 (2006).

22. F. La Mantia, F. Rosciano, N. Tran, and P. Novák, J. Appl. Electrochem., 38, 893 (2008).

23. D. Streich, A. Guéguen, M. Mendez, F. Chesneau, P. Novák, and E. J. Berg, J. Electrochem. Soc., 163, A964 (2016).

24. H. Yu, H. Kim, Y. Wang, P. He, D. Asakura, Y. Nakamura, and H. Zhou, Phys. Chem. Chem. Phys., 14, 6584 (2012).

25. N. Yabuuchi, K. Yoshii, S.-T. Myung, I. Nakai, and S. Komaba, J. Am. Chem. Soc., 133, 4404 (2011)

26. H. Koga, L. Croguennec, M. Ménétrier, P. Mannessiez, F. Weill, C. Delmas, and S. Belin, J. Phys. Chem. C, 118, 5700 (2014).

27. K. Luo, M. R. Roberts, R. Hao, N. Guerrini, D. M. Pickup, Y.-S. Liu, K. Edström, J. Guo, A. V. Chadwick, L. C. Duda, and P. G. Bruce, Nat. Chem., 8, 684 (2016).

28. A. Boulineau, L. Simonin, J.-F. Colin, E. Canévet, L. Daniel, and S. Patoux, Chem. Mater, 24, 3558 (2012).

29. A. Boulineau, L. Simonin, J.-F. Colin, C. Bourbon, and S. Patoux, Nano Lett., 13 3857 (2013).

30. C. Genevois, H. Koga, L. Croguennec, M. Ménétrier, C. Delmas, and F. Weill, J. Phys. Chem. C, 119, 75 (2015)

31. S. Meini, M. Piana, N. Tsiouvaras, A. Garsuch, and H. A. Gasteiger, Electrochem. Solid-State Lett., 15, A45 (2012).

32. N. Tsiouvaras, S. Meini, I. Buchberger, and H. A. Gasteiger, J. Electrochem. Soc., 160, A471 (2013).

33. F. Amalraj, M. Talianker, B. Markovsky, D. Sharon, L. Burlaka, G. Shafir, E. Zinigrad, O. Haik, D. Aurbach, J. Lampert, M. Schulz-Dobrick, and A. Garsuch, J. Electrochem. Soc., 160, A324 (2012).

34. J. R. Croy, K. G. Gallagher, M. Balasubramanian, Z. Chen, Y. Ren, D. Kim, S.-H. Kang, D. W. Dees, and M. M. Thackeray, J. Phys. Chem. C, 117, 6525 (2013).
35. M. Metzger, B. Strehle, S. Solchenbach, and H. A. Gasteiger, J. Electrochem. Soc., 163, A798 (2016).

36. B. D. McCloskey, D. S. Bethune, R. M. Shelby, G. Girishkumar, and A. C. Luntz, J. Phys. Chem. Lett., 2, 1161 (2011).

37. S. Meini, N. Tsiouvaras, K. U. Schwenke, M. Piana, H. Beyer, L. Lange, and H. A. Gasteiger, Phys. Chem. Chem. Phys., 15, 11478 (2013).

38. K. Matsumoto, R. Kuzuo, K. Takeya, and A. Yamanaka, J. Power Sources, 81-82, 558 (1999).

39. N. Mijung, Y. Lee, and J. Cho, J. Electrochem. Soc., 153, A935 (2006).

40. S.-W. Lee, H. Kim, M.-S. Kim, H.-C. Youn, K. Kang, B.-W. Cho, K. C. Roh, and K.-B. Kim, J. Power Sources, 315, 261 (2016).

41. S. A. Freunberger, Y. Chen, Z. Peng, J. M. Griffin, L. J. Hardwick, F. Bardé, P. Novák, and P. G. Bruce, J. Am. Chem. Soc., 133, 8040 (2011).

42. V. S. Bryantsev, V. Giordani, W. Walker, M. Blanco, S. Zecevic, K. Sasaki, J. Uddin, D. Addison, and G. V. Chase, J. Phys. Chem. A, 115, 12399 (2011).

43. M. Stylidi, D. I. Kondarides, and X. E. Verykios, Appl. Catal. B Environ., 47, 189 (2004).

44. N. Yabuuchi, Y.-T. Kim, H. H. Li, and Y. Shao-Horn, Chem. Mater, 20, 4936 (2008).

45. S.-M. Bak, K.-W. Nam, W. Chang, X. Yu, E. Hu, S. Hwang, E. A. Stach, K.-B. Kim, K. Y. Chung, and X.-Q. Yang, Chem. Mater, 25, 337 (2013).

46. S.-M. Bak, E. Hu, Y. Zhou, X. Yu, S. D. Senanayake, S.-J. Cho, K.-B. Kim, K. Y. Chung, X.-Q. Yang, and K.-W. Nam, ACS Appl. Mater. Interfaces, 6, 22594 (2014).

47. A. K. Shukla, Q. M. Ramasse, C. Ophus, H. Duncan, F. Hage, and G. Chen, Nat. Commun., 6, 8711 (2015).

48. B. Qiu, M. Zhang, L. Wu, J. Wang, Y. Xia, D. Qian, H. Liu, S. Hy, Y. Chen, K. An, Y. Zhu, Z. Liu, and Y. S. Meng, Nat. Commun., 7, 12108 (2016).

49. H. Koga, L. Croguennec, P. Mannessiez, M. Ménétrier, F. Weill, L. Bourgeois, M. Duttine, E. Suard, and C. Delmas, J. Phys. Chem. C, 116, 13497 (2015).

50. P. Yan, A. Nie, J. Zheng, Y. Zhou, D. Lu, X. Zhang, R. Xu, I. Belharouak, X. Zu, J. Xiao, K. Amine, J. Liu, F. Gao, R. Shahbazian-Yassar, J.-G. Zhang, and C.-M. Wang, Nano Lett., 15, 514 (2015).

51. D. P. Abraham, R. D. Twesten, M. Balasubramanian, I. Petrov, J. McBreen, and K. Amine, Electrochem. Commun., 4, 620 (2002).

52. S. Muto, Y. Sasano, K. Tatsumi, T. Sasaki, K. Horibuchi, Y. Takeuchi, and Y. Ukyo, J. Electrochem. Soc., 156, A371 (2009).

53. L. Wu, K.-W. Nam, X. Wang, Y. Zhou, J.-C. Zheng, X.-Q. Yang, and Y. Zhu, Chem. Mater., 23, 3953 (2011).

54. S.-K. Jung, H. Gwon, J. Hong, K.-Y. Park, D.-H. Seo, H. Kim, J. Hyun, W. Yang, and K. Kang, Adv. Energy Mater., 4, 1300787 (2014).

55. R. Jung, M. Metzger, F. Maglia, C. Stinner, and H. A. Gasteiger, Manuscript in preparation.

56. J. Hong, H. D. Lim, M. Lee, S. W. Kim, H. Kim, S. T. Oh, G. C. Chung, and K. Kang, Chem. Mater, 24, 2692 (2012).

57. A. Guéguen, D. Streich, M. He, M. Mendez, F. F. Chesneau, P. Novák, and E. J. Berg, J. Electrochem. Soc., 163, A1095 (2016) 